\title{
The Use of ISSR and RAPD Markers for Genetic Diversity among South Tunisian Barley
}

\author{
Ferdaous Guasmi, Walid Elfalleh, Hédia Hannachi, Khadija Fères, Leila Touil, \\ Nidhal Marzougui, Tebra Triki, and Ali Ferchichi \\ Laboratoire d'Aridoculture et Cultures Oasiennes, Institut des Régions Arides de Médenine, 4119 Médenine, Tunisia \\ Correspondence should be addressed to Ferdaous Guasmi, guasmifer@yahoo.fr
}

Received 20 August 2011; Accepted 2 October 2011

Academic Editors: M. Arias-Estévez and I. Vasilakoglou

Copyright (C) 2012 Ferdaous Guasmi et al. This is an open access article distributed under the Creative Commons Attribution License, which permits unrestricted use, distribution, and reproduction in any medium, provided the original work is properly cited.

Random amplified polymorphic DNA (RAPD) and intersimple sequence repeat (ISSR) were assayed to determine the genetic diversity of 80 barley specimens from South Tunisia. The ISSR primers showed variation in the percentage of polymorphism, band informativeness $(\mathrm{Ib})$, and resolving power $(\mathrm{Rp})$. The percentage of polymorphism is $66.67 \%$, the average Ib ranged from 0.24 to 0.39 , while $\mathrm{Rp}$ ranged from 0.74 to 1.16 . In RAPD analysis, three primers yielded a total of 17 scorable bands, which are all polymorphic. The three polymorphic primers exhibited variation with regard to average band informativeness (AvIb) and resolving power (Rp). RAPD and ISSR marker systems were found to be useful for the genetic diversity among the barley specimens. The two dendrograms obtained through these markers show different clustering of 80 barely specimens, but we noted that some clusters were similar in some cases. A poor correlation $(r=0.12)$ was found between both sets of genetic similarity data, suggesting that both sets of markers revealed unrelated estimates of genetic relationships. Therefore, the ISSR and RAPD molecular markers show two genetic grouping of studied barely specimens.

\section{Introduction}

Barley (Hordeum vulgare L.) is one of the most important crop species in the World and has been subject to considerable genetic studies. It is a diploid $(2 n=2 x=14)$, largely self-fertilizing species with a large genome [1].

Barley is cultivated on about 450.000 hectares in Tunisia. During centuries, early domestication and local knowledge have generated diverse local barley used mainly for feed and lowly for food [2]. In semiarid regions, barley is mostly cultivated by sheep owners and gazed one or two times as early winter crop when forage and pasture are not available. The conservation and use of plant genetic resources are essential to the continued maintenance and improvement of agricultural production.

The identification of varieties of crop plants has become increasingly important to the documentation of genetic resources and to the protection of the breeders' interests. To the malting and brewing industries, this is especially important because different varieties of barley (Hordeum vulgare L. ssp. vulgare) have widely different qualities and use characteristics. Farmers need positive identification for the protection of their proprietary rights on varieties. The grower needs assurance that the seed lot is of the variety he intends to use. Processors must be assured of varietal identity and that it is free from mixtures. Examination of grain morphological characteristics is the standard method of identifying barley cultivars, but not all of them can be distinguished on this basis. Several biochemical techniques have been used to complement morphological examination of barley cultivars, and most of them rely on variations among isoenzymes [3] and seed storage proteins [4]. Nevertheless, characterization with these kinds of markers was not very efficient for barley varieties due to the low levels of allelic variation in many isoenzymatic loci, the high degree of genetic relationship among the different varieties, and the high degree of polymorphism within barley varieties.

Molecular markers have been proved to be valuable tools in the characterization and evaluation of genetic diversity within and between species and populations. It has been showed that different markers might reveal different classes of variation $[5,6]$. It is correlated with the genome 
fraction surveyed by each kind of marker, their distribution throughout the genome and the extent of the DNA target which is analyzed by each specific assay [7]. The advent of the polymerase chain reaction (PCR) favored the development of different molecular techniques such as random amplified of polymorphic DNA (RAPD), simple sequence repeats (SSR or microsatellite), sequence-tagged sites (STS), random amplified microsatellite polymorphism (RAMP), and intersimple sequence repeat polymorphic DNA (ISSR) [8]. These molecular markers had been used in barley for detecting genetic diversity, genotype identification, and genetic mapping [911]. Of these techniques, RAPD has several advantages, such as simplicity of use, low cost, and the use of small amount of plant material. RAPDs were proved to be useful as genetic markers in the case of self-pollinating species with a relatively low level of intraspecific polymorphism, such as hexaploid wheat $[12,13]$ and cultivated barley [14]. Bernard et al. [15], used RAPD markers and have revealed extensive polymorphism between different genotypes of wild barley. They showed that out of total genetic diversity estimated, $75 \%$ of the variation detected was partitioned within the genotypes and $25 \%$ among the populations, whereas no substantial differences were found between countries. ISSR markers, which involve PCR amplifications of DNA using a primer, composed of a microsatellite sequence anchored at $3^{\prime}$ or $5^{\prime}$ end by 2-4 arbitrary, could be used to assess genetic diversity [16]. ISSRs have been used for cultivar identification for potatoes [17], wheat [18], bean [19], and barley $[10,11]$.

In this study, we evaluate the level and organization of the genetic diversity and relationship in barely specimens cultivated in south Tunisia using RAPD and ISSR markers, in order to establish a base line to assist future conservation and breeding programmes of this species. Also we aim to report the usefulness of RAPD and ISSR for the assessment of genetic diversity and relationships among barley specimens.

\section{Materials and Methods}

2.1. Plant Material. Eighty barley (Hordeum vulgare L.) specimens selected from "Institut des régions arides de Médenine" (South Tunisia) were used in this study. The specimen numbers and country of origin are listed in Table 1.

2.2. DNA Extraction. Total DNA was extracted from fresh leaves as described by J. J. Doyle and J. L. Doyle [20] with some modifications. DNA concentration was determined by both spectrophotometry at $260 \mathrm{~nm}$ and by $2 \%$ agarose gel electrophoresis.

2.3. ISSR-PCR Analysis. A set of 10 ISSR primers was procured from Operon molecular for life (Table 2). Initially 3 specimens were used for PCR amplification using all the 10 primers. Three primers gave clear and polymorphic patterns and were used for further analysis of 80 specimens. For each primer, $20 \mu \mathrm{L}$ amplification reaction contained $2.5 \mu \mathrm{L}$ buffer (Taq Buffer avec $\left(\mathrm{NH}_{4}\right)_{2} \mathrm{SO}_{4} 5 \mathrm{x}$ ), $100 \mathrm{ng}$ of genomic
DNA, $2 \mathrm{mM}$ of $\mathrm{MgCl}_{2}$ and $1 \mathrm{U}$ of Taq DNA polymerase. PCR amplifications were performed in gen-Amp PCR 9700 thermal cycler system, with initial denaturation at $94^{\circ} \mathrm{C}$ for $5 \mathrm{~min}$ followed by 35 cycles: denaturation at $94^{\circ} \mathrm{C}$ for $1 \mathrm{~min}$, annealing at $36^{\circ} \mathrm{C}$ for $1 \mathrm{~min}$, extension at $72^{\circ} \mathrm{C}$ for $2 \mathrm{~min}$, with final extension at $72^{\circ} \mathrm{C}$ for $7 \mathrm{~min}$. PCR products were separated on $2 \%$ agarose gels, stained with ethidium bromide, and visualised on UV. The gel was photographed using Bio-print camera.

2.4. RAPD-PCR Analysis. RAPD analysis was carried out with 10 decamer random primers from Operon molecular for life (Table 2). PCR amplifications were carried out also with 3 specimens. Three primers gave clear and polymorphic amplification patterns and were used for further analysis of 80 specimens. For each primer, $20 \mu \mathrm{L}$ amplification reaction contained: $100 \mathrm{ng}$ of genomic DNA, $5 \mathrm{mM}$ of $\mathrm{MgCl}_{2}, 1 \mathrm{U}$ of Taq DNA polymerase, and $4 \mu \mathrm{L}$ de buffer (Taq Buffer avec $\left.\left(\mathrm{NH}_{4}\right)_{2} \mathrm{SO}_{4} 10 \mathrm{x}\right)$. PCR amplifications were performed in a gen-Amp PCR 9700 thermal cycler system. The PCR conditions included initial denaturation at $94^{\circ} \mathrm{C}$ for $5 \mathrm{~min}$, followed by 45 cycles: denaturation at $92^{\circ} \mathrm{C}$ for $1 \mathrm{~min}$, annealing at $50^{\circ} \mathrm{C}$ for $2 \mathrm{~min}$ and extension at $72^{\circ} \mathrm{C}$ for $2 \mathrm{~min}$ with final extension at $72^{\circ} \mathrm{C}$ for $7 \mathrm{~min}$.

2.5. Reproducibility of Amplification Patterns. DNA amplifications with each ISSR and RAPD primers were repeated at least thrice to ensure reproducibility. The bands were considered reproducible and scorable only after observing and comparing them in three separate amplifications for each primer. Clear and intense bands were scored while faint bands against background smear were not considered for the further analysis.

2.6. Scoring and Data Analysis. For each specimen, each fragment/band that was amplified using ISSR and RAPD primers was treated as unit character. Molecular weight of each of the potential specific bands was calculated using the software Gel-pro analyser. Unequivocally scorable and consistently reproducible amplified DNA fragments were transformed into binary character matrices (1 for presence, 0 for absence). The commercial software package SPSS 16 was used to develop similarity matrices based on the Dice coefficient which is defined as $2 a / 2 a+u$, where " $a$ " is the number of positive matches and " $u$ " is the number of nonmatches. These data were then used to construct dendrogram for cluster analysis based on the Dice coefficient and on the simple link as the algorithm aggregation method. Two separate dendrograms for ISSR and RAPD data were generated. The distance matrices obtained in RAPD and ISSR analyses were compared using correlation analysis. Average band informativeness (AvIb) is a measure of closeness of a band to be present in $50 \%$ of the genotypes under study, and resolving power $(\mathrm{Rp})$ is the sum of $\mathrm{Ib}$ values of all the bands amplified by a primer. Band informativeness (Ib) and resolving power $(\mathrm{Rp})$ were calculated as given by Prevost and 
TABLE 1: Studied barley specimens and their geographical origins.

\begin{tabular}{|c|c|c|c|c|c|}
\hline & Specimens name & Code & Location & Region & Provence \\
\hline 1 & Elmejni & 19 & Elmejni & Gabes & Gabes \\
\hline 2 & Elmdou & 43 & Elmdou & Gabes & Gabes \\
\hline 3 & Mazreet ben slama & 74 & Mazreet ben slama & Gabes & Gabes \\
\hline 4 & Mareth & 10 & Mareth & Mareth & Gabes \\
\hline 5 & Aiin tounine & 69 & Aiin tounine & Matmata & Gabes \\
\hline 6 & Dkilet toujene & 17 & Dkilet toujene & Matmata & Gabes \\
\hline 7 & Matmatta jdida 1 & 30 & Matmatta jdida & Matmata & Gabes \\
\hline 8 & Matmata jdida 2 & 34 & Matmata jdida & Matmata & Gabes \\
\hline 9 & Zmerten & 50 & Zmerten & Matmata & Gabes \\
\hline 10 & Belkir & 20 & Belkir & Belkir & Gafsa \\
\hline 11 & Belkhir 3 & 22 & Belkhir & Belkhir & Gafsa \\
\hline 12 & Essaidane & 29 & Essaidane & Ben Guerdane & Medenine \\
\hline 13 & Bniri & 48 & Bniri & Ben guerdane & Medenine \\
\hline 14 & Oued erbaii & 49 & Oued erbaii & Ben guerdane & Medenine \\
\hline 15 & Jellala & 70 & Jellala & Ben guerdane & Medenine \\
\hline 16 & Oued el khil 2 & 4 & Oued el khil & Ben keddache & Medenine \\
\hline 17 & Labyar 2 & 11 & Labyar & Ben keddache & Medenine \\
\hline 18 & Manzel mgor 1 & 26 & Manzel mgor & Ben khddache & Medenine \\
\hline 19 & Manzel mgor 2 & 27 & Manzel mgor & Ben khddache & Medenine \\
\hline 20 & Labyar 1 & 35 & Labyar & Ben khddache & Medenine \\
\hline 21 & Switir 1 & 77 & Switir & Medenine & Medenine \\
\hline 22 & Swittir & 12 & Swittir & Medenine & Medenine \\
\hline 23 & Bir ezwai & 13 & Bir ezwai & Medenine & Medenine \\
\hline 24 & El bhira 1 & 31 & El bhira & Medenine & Medenine \\
\hline 25 & El bhira 2 & 32 & El bhira & Medenine & Medenine \\
\hline 26 & Hjar & 36 & Hjar & Medenine & Medenine \\
\hline 27 & Tarf ellil & 41 & Tarf ellil & Medenine & Medenine \\
\hline 28 & Ben khddache centre & 44 & Ben khddache centre & Medenine & Medenine \\
\hline 29 & Bir ezzwai & 46 & Bir ezzwai & Medenine & Medenine \\
\hline 30 & Ferjania 2 & 53 & Ferjania & Medenine & Medenine \\
\hline 31 & Oued elhalouf & 56 & Oued elhalouf & Medenine & Medenine \\
\hline 32 & Ksar ejdid & 59 & Ksar ejdid & Medenine & Medenine \\
\hline 33 & Lagrabette & 63 & Lagrabette & Medenine & Medenine \\
\hline 34 & Ben gzayel & 73 & Ben gzayel & Medenine & Medenine \\
\hline 35 & Thahret el gbour 2 & 57 & Thahret el gbour & Medenine & Medenine \\
\hline 36 & Thahret elgbour & 71 & Thahret elgbour & Medenine & Medenine \\
\hline 37 & Errssifett & 37 & Errssifett & Zarzis & Medenine \\
\hline 38 & Essolb & 51 & Essolb & Zarzis & Medenine \\
\hline 39 & Orge Pakestani & 79 & Orge Pakestani & Pakistan & Pakistan \\
\hline 40 & Echahbania 1 & 2 & Echahbania & Tataouine & Tataouine \\
\hline 41 & Tataouine ejdida & 3 & Tataouine ejdida & Tataouine & Tataouine \\
\hline 42 & El bagbag 3 & 6 & El bagbag & Tataouine & Tataouine \\
\hline 43 & Lamaat & 7 & Lamaat & Tataouine & Tataouine \\
\hline 44 & El ferch 1 & 8 & El ferch & Tataouine & Tataouine \\
\hline 45 & Ksar ouled boubaker & 9 & Ksar ouled boubaker & Tataouine & Tataouine \\
\hline 46 & Tlalite & 14 & Tlalite & Tataouine & Tataouine \\
\hline 47 & Bir 30 & 15 & Bir 30 & Tataouine & Tataouine \\
\hline 48 & Oued el khil & 16 & Oued el khil & Tataouine & Tataouine \\
\hline 49 & Amadi & 18 & Amadi & Tataouine & Tataouine \\
\hline 50 & Mgitt 2 & 21 & Mgitt & Tataouine & Tataouine \\
\hline
\end{tabular}


Table 1: Continued.

\begin{tabular}{|c|c|c|c|c|c|}
\hline & Specimens name & Code & Location & Region & Provence \\
\hline 51 & Missawa & 23 & Missawa & Tataouine & Tataouine \\
\hline 52 & Gomrassen & 24 & Gomrassen & Tataouine & Tataouine \\
\hline 53 & Gattouffa & 25 & Gattouffa & Tataouine & Tataouine \\
\hline 54 & Bir lahmer 2 & 28 & Bir lahmer & Tataouine & Tataouine \\
\hline 55 & El bag bag 1 & 33 & El bag bag & Tataouine & Tataouine \\
\hline 56 & Erremtha 2 & 38 & Erremtha & Tataouine & Tataouine \\
\hline 57 & El ferch 2 & 39 & El ferch & Tataouine & Tataouine \\
\hline 58 & Oued el khil 3 & 42 & Oued el khil & Tataouine & Tataouine \\
\hline 59 & Misstawa1 & 45 & Missawa & Tataouine & Tataouine \\
\hline 60 & Grager 2 & 47 & Grager & Tataouine & Tataouine \\
\hline 61 & Gormassa & 52 & Gormassa & Tataouine & Tataouine \\
\hline 62 & Ksar oun 1 & 54 & Ksar oun & Tataouine & Tataouine \\
\hline 63 & Bir addim & 55 & Bir addim & Tataouine & Tataouine \\
\hline 64 & Ksar ouled dbab & 58 & Ksar ouled dbab & Tataouine & Tataouine \\
\hline 65 & El mawouna & 60 & El mawouna & Tataouine & Tataouine \\
\hline 66 & Ezzahra 2 & 61 & Ezzahra & Tataouine & Tataouine \\
\hline 67 & Elmziraa & 62 & Elmziraa & Tataouine & Tataouine \\
\hline 68 & Bouzrida & 64 & Bouzrida & Tataouine & Tataouine \\
\hline 69 & Echahbania & 65 & Echahbania & Tataouine & Tataouine \\
\hline 70 & Gormassa 2 & 66 & Gormassa & Tataouine & Tataouine \\
\hline 71 & Lahyet mars & 67 & Lahyet mars & Tataouine & Tataouine \\
\hline 72 & Gomrassen 1 & 68 & Gomrassen & Tataouine & Tataouine \\
\hline 73 & Elbagbag 2 & 72 & Elbagbag & Tataouine & Tataouine \\
\hline 74 & Gragre 1 & 75 & Gragre & Tataouine & Tataouine \\
\hline 75 & Oued el khil 1 & 76 & Oued el khil & Tataouine & Tataouine \\
\hline 76 & Chenenni & 78 & Chenenni & Tataouine & Tataouine \\
\hline 77 & Gasbett gomri & 5 & Gasbett gomri & Tataouine & Tataouine \\
\hline 78 & Chehbania 2 & 40 & Chehbania & Tataouine & Tataouine \\
\hline 79 & El mourra & 1 & El mourra & Tataouine & Tataouine \\
\hline 80 & Rihane & 80 & Rihane & Tunis & Tunis \\
\hline
\end{tabular}

Wilkinson [17]. The formulae used for the above-mentioned parameters are

(i) Band informativeness of a given band: $\mathrm{Ib}=1-(2 \times$ $|0.5-p|)$, where $p$ is the proportion of the total genotypes containing the band;

(ii) resolving power of a primer is the sum of band informativeness: $\mathrm{Rp}=\Sigma \mathrm{Ib}$.

The hierarchical classification ascendant (HCA) was conducted on ISSR and RAPD data based on dissimilarity (Dice index) and the simple link as the algorithm aggregation method.

\section{Results}

3.1. Identification and Evaluation of RAPD and ISSR Primers for Diversity Estimation. Out of 10 decamer random primers used for initial screening with three representative genotypes, only three primers amplified polymorphic patterns. These primers were then used for RAPD analysis of all the 80 genotypes. Amplification products of the 80 genotypes with these three primers yielded a total of 17 scorable bands, which are all polymorphic (Table 3 ). The highest number of bands (8) was obtained with primer BY-15, while the lowest number (4) was obtained with primer UBC-402. Different primers showed the same variation in their ability to detect polymorphism (100\%). The three polymorphic primers exhibited variation with regard to average band informativeness (AvIb) and resolving power (Rp). The AvIb and $\mathrm{Rp}$ values of these polymorphic primers have been depicted in Table 6. The primer OPA-11 showed the lowest AvIb (0.37) and Rp (1.85), while the highest AvIb (0.65) and $\mathrm{Rp}$ (5.20) values were exhibited by the primers BY-15.

For ISSR markers, a total of 10 primers consisting of diand tri-repeat motifs were used for initial screening with 3 specimens. Out of these, 7 primers gave no amplification at all, while only 3 primers were found to give clear and polymorphic patterns and were subsequently used to analyze the entire set of 80 genotypes. These ISSR primers amplified a total of 9 bands out of which 6 bands were polymorphic. These primers showed variation in the percentage of polymorphism band informativeness ( $\mathrm{Ib}$ ) and resolving power $(\mathrm{Rp})$. The percentage of polymorphism is $66.66 \%$; 
TABLE 2: ISSR and RAPD primers tested in this study.

\begin{tabular}{lcc}
\hline & ISSR primers & Sequence of primer $\left(5^{\prime}-3^{\prime}\right)$ \\
\hline 1 & UBC-888 & BDBCACACACACACACA \\
2 & UBC-890 & VHVGTGTGTGTGTGTGT \\
3 & A12 & (GA) ${ }_{6}$ CC \\
4 & UBC-810 & GAGAGAGAGAGAGAGAT \\
5 & UBC-812 & GAGAGAGAGAGAGAGAA \\
6 & UBC-814 & CTCTCTCTCTCTCTCTA \\
7 & UBC-815 & CTCTCTCTCTCTCTCTG \\
8 & UBC-822 & TCTCTCTCTCTCTCTCA \\
9 & UBC-834 & AGAGAGAGAGAGAGAGYT \\
10 & UBC-845 & CTCTCTCTCTCTCTCTRG \\
\hline & RAPD Primers & Sequence of primer $\left(5^{\prime}-3^{\prime}\right)$ \\
\hline 1 & UBC- 402 & -CCCGCCGTTG- \\
2 & UBC-475 & -CCAGCGTATT- \\
3 & UBC-490 & -AGTCGACCTT- \\
4 & UBC-534 & -CACCCCCTGC- \\
5 & UBC-102 & -GGTGGGGACT- \\
6 & OPA-04 & -AATCGGGCTG- \\
7 & OPA-18 & -AGGTGACCGT- \\
8 & OPA-11 & -CAATCGCCGT- \\
9 & BY-15 & -CTCACCGTCC- \\
10 & W07 & -CTGGACGTCA- \\
\hline
\end{tabular}

the average $\mathrm{Ib}$ ranged from 0.24 to 0.39 while $\mathrm{Rp}$ ranged from 0.74 to 1.16 (Table 3 ). The primer UBC 890 showed the highest values of average Ib (0.39) and Rp (1.16).

\subsection{Genetic Diversity and Clustering Based on RAPD and} ISSR Polymorphism Data. The dendrogram obtained using RAPD data indicates nine main clusters (Figure 2, Table 5). The cluster 8 includes the specimen "Lahyet mars" collected from Tataouine, characterized by the low number of locus (only 3). The class 7 includes only two specimens "Thahet el gbour 2" from Médenine and "Grager 2" from Tataouine, which present the height number of locus (ten loci). The cluster 1 includes the majority of specimens (54 specimens), characterized by the absence of 2 locus having molecular size 900 and $390 \mathrm{pb}$, respectively. The position of specimens regrouped in clusters $6,9,11,12,13,14$, and 15 obtained by ISSR markers (Table 4 ), remained the same as in the RAPD dendrogram clusters 2, 4, 5, 6, 7, 8, and 9 .

According the ISSR data, a dendrogram was developed for 80 genotypes and indicates 18 main clusters; the cluster 5 includes 29 specimens (Table 3), characterized by the presence of 7 locus with molecular size ranging from 225 to $400 \mathrm{bp}$. The cluster 4 includes 18 specimens, characterized by the presence of 6 loci whose molecular size ranged from 225 to $300 \mathrm{bp}$. The different clusters $1,7,12$, and 18 would constitute one group characterized by the presence of 6 loci with variable molecular size. The cluster 13 includes two specimens "Ezzahra 2" and "Bouzrida" collected from Tataouine, having low number of bands: 2 loci whose molecular sizes were 275 and $295 \mathrm{pb}$. The specimen "Bir addim" from Tataouine included in cluster 11, covering 3 loci with molecular sizes 225, 275, and $300 \mathrm{pb}$.

3.3. Comparison of RAPD and ISSR Markers in Diversity Assessment of Barley Genotypes. The composition of clusters obtained using independently RAPD and ISSR markers have revealed similar groupings in only some clusters. The performance of these markers was evaluated using various parameters such as percentage of polymorphism, average band informativeness, resolving power, and clusters formed in the dendrogram. The comparison of these parameters done using two marker systems is summarized in Table 6. Percentage of polymorphic markers: the three ISSR primers yielded average three bands per primer, while the three RAPD primers amplified average 5.66 bands per primer. The average number of polymorphic bands per primer was higher in case of RAPDs (5.22) as compared to that in ISSRs (2). The range of band informativeness (Ib) values of both marker systems is reported in Table 6 . The highest value (0.49) displayed by RAPD markers is higher than the ISSR markers (0.30). Resolving power is a characteristic of a primer which reflects overall suitability of a marker system for the purpose of identification, as it is related to the number of specimens distinguished by that primer [17]. Rp value for both RAPD and ISSR polymorphic primers was calculated, and it was observed that RAPD primers had greater Rp (2.99) than ISSR primers (0.92).

The correlation coefficient for the elements of the RAPD GS (Genetic Similarity) and ISSR-GS matrices was calculated using the mantel test [21]. There was no significant correlation $(r=0.12)$ between the RAPD GS and ISSR-GS matrices, indicating that both sets of markers revealed the unrelated estimates of genetic relationships.

\section{Discussion}

The results indicated that the percentage of RAPD polymorphic bands (100\%) was higher than that of ISSR $(66.67 \%)$. The mean number of amplification RAPD bands (5.66) was more than that of ISSR (3). Moreover, the total number of polymorphic bands (17) detected by three RAPD primers was much higher than that of the three ISSR primers (6), which suggested that the RAPD markers were superior to ISSR markers in the capacity of revealing more informative bands in a single amplification. The similar results were observed by Fernández et al. [11] and Tanyolac [10].

Due to its worldwide distribution, the valuation of the genetic diversity among barley germplasm from different countries has been performed [7, 9, 11, 22-24]. Bernard et al. [15] analyzed the genetic diversity in 88 genotypes from 20 populations of wild barley from Israel, Turkey, and Iran by RAPD markers. When the total genetic diversity were estimated, $75 \%$ of the variation detected was partitioned within the 88 genotypes and 25\% among the populations. When variation between countries was assessed, no substantial differences were found, because most of the variation detected (97\%) was partitioned within the 20 populations and the remainder among the countries. Therefore, 
TABLE 3: Polymorphism exhibited by ISSR and RAPD primers in barley.

\begin{tabular}{|c|c|c|c|c|c|c|c|c|}
\hline & \multirow[t]{2}{*}{ Primers } & \multicolumn{2}{|c|}{$\operatorname{Tm}\left({ }^{\circ} \mathrm{C}\right)$} & \multirow[t]{2}{*}{ Total bands } & \multirow[t]{2}{*}{ Polymorphic } & \multirow[t]{2}{*}{ (\%) Polymorphism } & \multirow{2}{*}{$\begin{array}{c}\text { Resolving } \\
\text { power }(\mathrm{Rp})\end{array}$} & \multirow{2}{*}{$\begin{array}{c}\text { Average of } \\
\text { informativeness } \\
\text { bands (AvIb) }\end{array}$} \\
\hline & & Theoretical & Optimal & & & & & \\
\hline \multirow{5}{*}{ ISSR } & UBC-890 & 56.39 & 56 & 3 & 2 & 66.67 & 1.16 & 0.39 \\
\hline & UBC- 888 & 56.39 & 55 & 3 & 2 & 66.67 & 0.86 & 0.29 \\
\hline & A12 & 55 & 55 & 3 & 2 & 66.67 & 0.74 & 0.24 \\
\hline & Total & - & - & 9 & 6 & - & - & - \\
\hline & Mean & - & - & - & - & 66.67 & 0.92 & 0.30 \\
\hline \multirow{5}{*}{ RAPD } & UBC-402 & 55 & 47 & 4 & 4 & 100 & 1.90 & 0.47 \\
\hline & OPA-11 & 50 & 47.5 & 5 & 5 & 100 & 1.89 & 0.37 \\
\hline & BY-15 & 32 & 34 & 8 & 8 & 100 & 5.20 & 0.65 \\
\hline & total & - & - & 17 & 17 & - & - & - \\
\hline & Mean & - & - & - & - & 100 & 2.99 & 0.49 \\
\hline
\end{tabular}

Rp: Resolving power.

Ib: Band informativeness.

TABLE 4: Different classes obtained by dendrogram clustering using ISSR data.

\begin{tabular}{ll}
\hline Cluster & Specimens code \\
\hline C1 & 1 \\
C2 & $2,3,23,49$ \\
C3 & $4,17,56,59,66$ \\
C4 & $5,6,7,8,14,15,16,18,26,31,45,50,51,52$, \\
& $62,71,72,74$ \\
C5 & $9,10,11,12,19,20,21,22,24,25,28,29,30$, \\
& $32,34,35,36,37,38,39,40,41,42,44,46,48$, \\
C6 & $73,75,77$ \\
C7 & 13 \\
C8 & $27,33,58$ \\
C9 & 43 \\
C10 & 47,57 \\
C11 & $53,54,63,65,69,76$ \\
C12 & 55 \\
C13 & 60 \\
C14 & 61,64 \\
C15 & 67 \\
C16 & 70 \\
C17 & 78 \\
C18 & 79 \\
\hline
\end{tabular}

the barely specimens were closed together independently of their geographic origin. In this study, both dendrograms based on RAPD and on ISSR markers do not show geographic profiling between barely specimens (Figures 1 and 2 ). Moreover, it has been reported that the dendrogram generated by the ISSR matrix agrees better with the genealogy and the known pedigree of the barley cultivars than the dendrogram generated by the RAPD results [11]. On the other hand, it has been found that the data based on RAPD-GS
TABLE 5: Different classes obtained by dendrogram clustering using RAPD data.

\begin{tabular}{ll}
\hline Cluster & Specimens code \\
& $1,2,3,5,6,8,9,10,11,1214,15,16,20,21,22,23,24$, \\
C1 & 25, 26, 28, 31, 34, 35, 40, 42, 43, 44 73, 75, 49, 50, 51, \\
& $53,56,30,52,54,27,6265,66,72,7632,60,69,71,58$, \\
& $594,41,37,77$ \\
C2 & 61,64 \\
C3 & $7,17,18,19,2936,33,38,3940,63,787980,48,45$ \\
C4 & 55 \\
C5 & 70 \\
C6 & 13,68 \\
C7 & 47,57 \\
C8 & 67 \\
C9 & 69
\end{tabular}

TABLE 6: Comparison of polymorphism detected by RAPD and ISSR markers in 80 barley specimens.

\begin{tabular}{lccc}
\hline & $\begin{array}{c}\text { Average } \\
\text { band/Primer }\end{array}$ & $\begin{array}{c}\text { Average polymorphic } \\
\text { band/Primer }\end{array}$ & $\begin{array}{c}\text { Correlation } \\
\text { RAPD/ISSR }\end{array}$ \\
\hline RAPD & 5.66 & 5.66 & \\
ISSR & 3 & 2 & 0.12 \\
\hline
\end{tabular}

were more correlated with the geographic distribution of the genus Houttuynia thunb, while the data based on ISSRs were closely related with their number of chromosomes [8]. It could be partially explained by the different number of informative PCR products (84 for RAPDs and 105 for ISSRs). They reinforced again the importance of the number of loci and their coverage of the overall genome and obtained reliable estimates of genetic relationship among the studied materials [11].

The microsatellites or intersimple sequence repeat (ISSR) markers and randomly amplified polymorphic DNA 


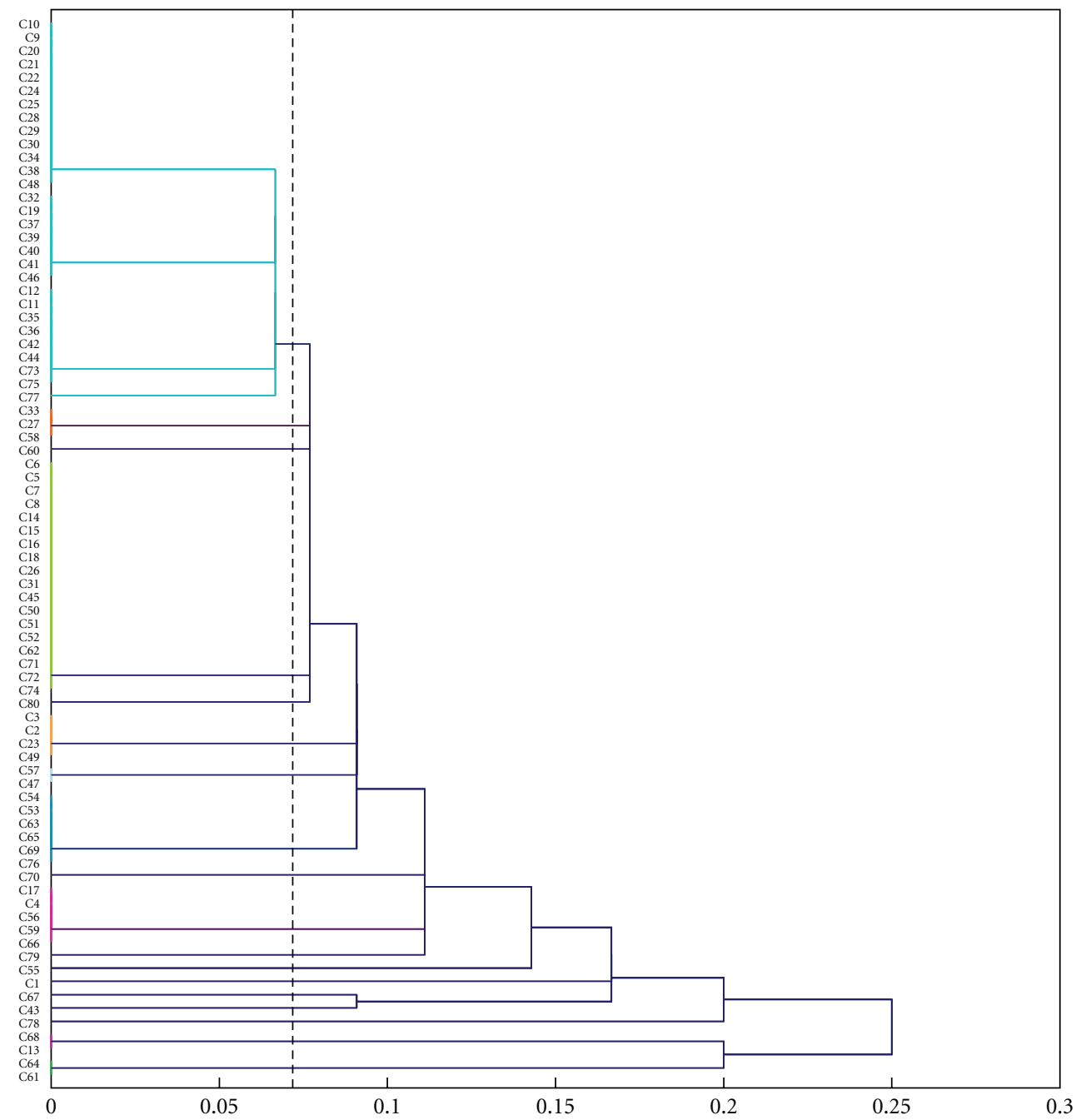

(a)

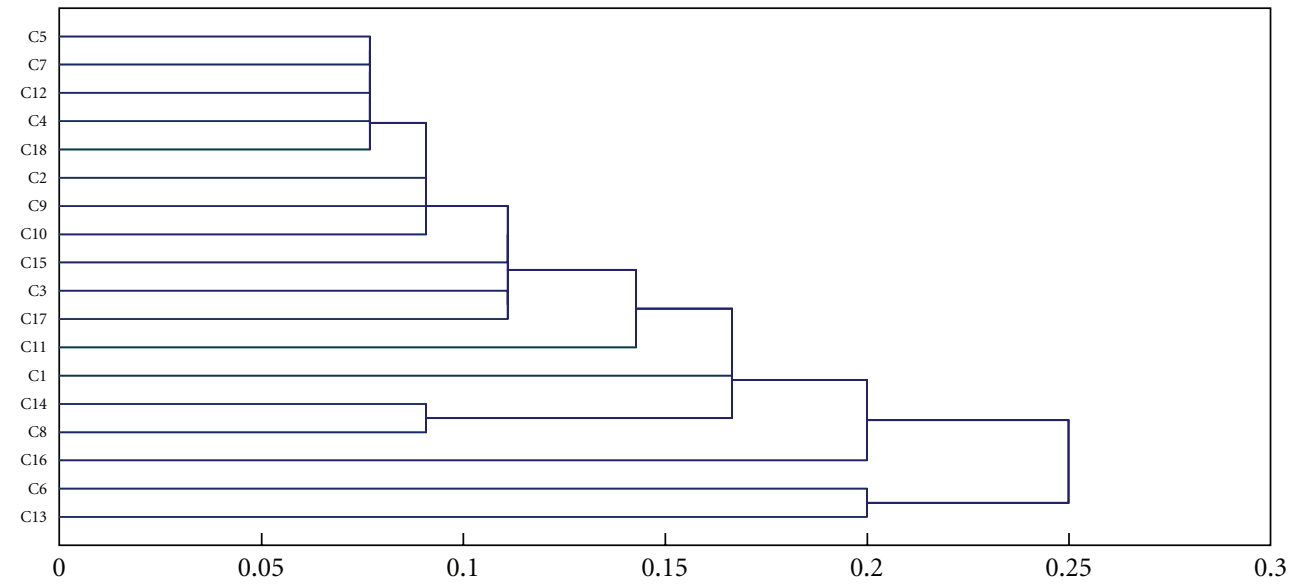

(b)

FIGURE 1: Dendrogram clustering revealed by 80 barley specimens (a) and clusters (b) using ISSR data and constructed based on the Dice dissimilarity index.

(RAPD) markers have proved to be the most polymorphic markers in barley and hence are highly useful markers for various applications in barley [11]. Apart from using them in diversity analysis, ISSR markers have been showed to be associated with various agronomically important traits, namely, dwarfing and vernalization response [25], leaf rust resistance [26], kernel hardness [27], cadmium uptake [28] preharvest sprouting tolerance [29], protein content [30] 


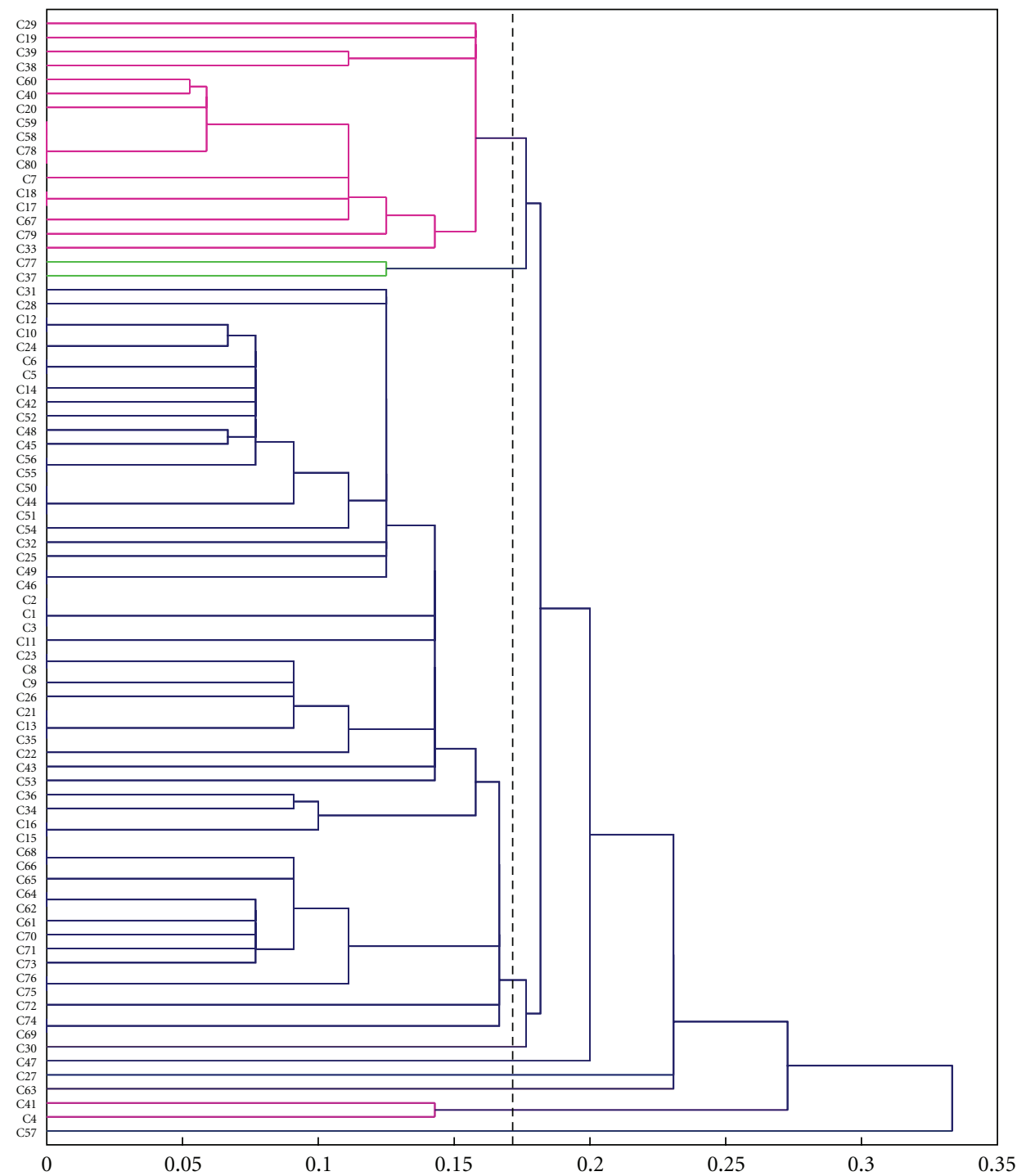

(a)

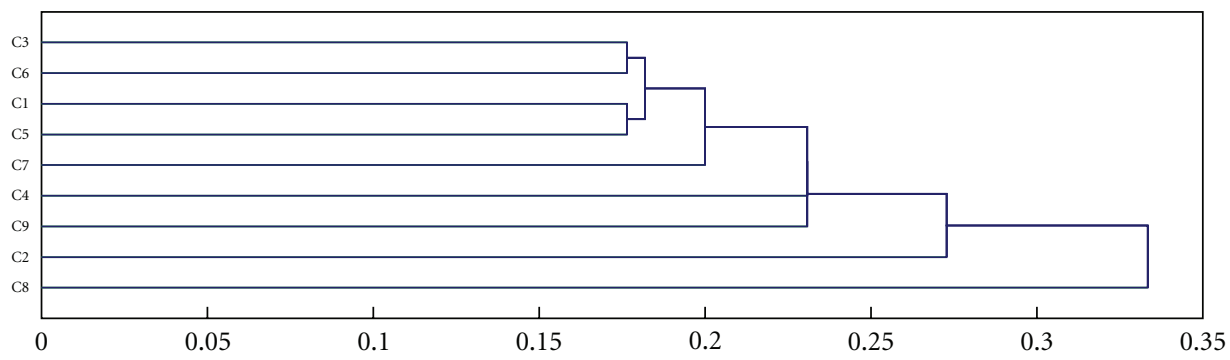

(b)

FIGURE 2: Dendrogram clustering revealed by 80 barley specimens (a) and clusters (b) using RAPD data and constructed based on the Dice dissimilarity index.

resistance to common bunt [31], powdery mildew resistance [32], kernel traits [33], flour viscosity [34]. RAPD markers were also shown to be associated with various traits such as the Aegilops speltoides leaf rust resistance gene Lr 28 in wheat [35], various traits contributing to kernel hardness in bread wheat [36], and cadmium intake in durum wheat [28]. These markers can be used for selection of important agronomic traits which would increase the efficiency and precision of breeding. In a previous study [37], some traits were used to evaluate the agronomical potentiality of barely specimens in south Tunisia. It has been noted that although the importance of agronomic parameters, it is necessary to use other markers to study diversity and select genotypes with high potential. 
Comparing our results with other work on the study of molecular polymorphism in barley by RAPD markers and using the same primers, we deduced differences in the number and size of bands. Among the primers used by Owuor et al. [38], to study the polymorphism in wild barley (Hordeum spontaneum) in Palestine, it has been noted that the OPA-04 and OPA-18 primers were also used for the study of diversity in Morocco barley specimens [39]. The UBC534 and UBC-490 primers were used to study the diversity of Palestine barley specimens [40].

According to molecular analysis, the geographical origin of specimens has no influence on the clusters obtained and seems to favor the hypothesis of the existence of a common origin for all barley cultivars. It has been assumed that the wild barley (Hordeum vulgare ssp. spontaneum) Tibet is the ancestor of cultivated barley worldwide [41].

\section{References}

[1] M. D. Bennett and J. B. Smith, "Nuclear DNA amounts in angiosperms," Philosophical Transactions of the Royal Society of London B, vol. 274, no. 933, pp. 227-274, 1976.

[2] N. I. Vavilov, "Phytogeographic basis of plant breeding: the origin variation immunity and breeding of cultivated plants," Chronica Botanica, vol. 13, pp. 361-366, 1951.

[3] S. Laugesen, K. S. Bak-Jensen, P. Hägglund et al., "Barley peroxidase isozymes. Expression and post-translational modification in mature seeds as identified by two-dimensional gel electrophoresis and mass spectrometry," International Journal of Mass Spectrometry, vol. 268, no. 2-3, pp. 244-253, 2007.

[4] P. C. Canci, L. M. Nduulu, R. Dill-Macky, G. J. Muehlbauer, D. C. Rasmusson, and K. P. Smith, "Genetic relationship between kernel discoloration and grain protein concentration in barley," Crop Science, vol. 43, no. 5, pp. 1671-1679, 2003.

[5] W. Powell, M. Morgante, C. Andre et al., "The comparison of RFLP, RAPD, AFLP and SSR (microsatellite) markers for germplasm analysis," Molecular Breeding, vol. 2, no. 3, pp. 225238, 1996.

[6] J. R. Russell, J. D. Fuller, M. Macaulay et al., "Direct comparison of levels of genetic variation among barley accessions detected by RFLPs, AFLPs, SSRs and RAPDs," Theoretical and Applied Genetics, vol. 95, no. 4, pp. 714-722, 1997.

[7] J. A. Dávila, Y. Loarce, L. Ramsay, R. Waugh, and E. Ferrer, "Comparison of RAMP and SSR markers for the study of wild barley genetic diversity," Hereditas, vol. 131, no. 1, pp. 5-13, 1999.

[8] K. S. Wu, R. Jones, L. Danneberger, and P. A. Scolnik, "Detection of microsatellite polymorphisms without cloning," Nucleic Acids Research, vol. 22, no. 15, pp. 3257-3258, 1994.

[9] I. A. Matus and P. M. Hayes, "Genetic diversity in three groups of barley germplasm assessed by simple sequence repeats," Genome, vol. 45, no. 6, pp. 1095-1106, 2002.

[10] B. Tanyolac, "Inter-simple sequence repeat (ISSR) and RAPD variation among wild barley (Hordeum. vulgare subsp. spontaneum) populations from west Turkey," Genetic Resources and Crop Evolution, vol. 50, no. 6, pp. 611-614, 2003.

[11] M. E. Fernández, A. M. Figueiras, and C. Benito, "The use of ISSR and RAPD markers for detecting DNA polymorphism, genotype identification and genetic diversity among barley cultivars with known origin," Theoretical and Applied Genetics, vol. 104, no. 5, pp. 845-851, 2002.
[12] K. M. Devos and M. D. Gale, "The use of random amplified polymorphic DNA markers in wheat," Theoretical and Applied Genetics, vol. 84, no. 5-6, pp. 567-572, 1992.

[13] C. P. Joshi and H. T. Nguyen, "RAPD (random amplified polymorphic DNA) analysis based intervarietal genetic relationships among hexaploid wheats," Plant Science, vol. 93, no. 1-2, pp. 95-103, 1993.

[14] N. A. Tinker, M. G. Fortin, and D. E. Mather, "Random amplified polymorphic DNA and pedigree relationships in spring barley," Theoretical and Applied Genetics, vol. 85, no. 8, pp. 976-984, 1993.

[15] R. B. Bernard, E. Nevo, A. J. Douglas, and A. Beiles, "Genetic diversity in wild barley (Hordeum spontaneum C. Koch) in the near east: a molecular analysis using random amplified polymorphic DNA (RAPD) markers," Genetic Resources and Crop Evolution, vol. 44, no. 2, pp. 147-157, 1997.

[16] W. Qian, S. Ge, and D. Y. Hong, "Genetic variation within and among populations of a wild rice Oryza granulata from China detected by RAPD and ISSR markers," Theoretical and Applied Genetics, vol. 102, no. 2-3, pp. 440-449, 2001.

[17] A. Prevost and M. J. Wilkinson, "A new system of comparing PCR primers applied to ISSR fingerprinting of potato cultivars," Theoretical and Applied Genetics, vol. 98, no. 1, pp. 107$112,1999$.

[18] T. Nagaoka and Y. Ogihara, "Applicability of inter-simple sequence repeat polymorphisms in wheat for use as DNA markers in comparison to RFLP and RAPD markers," Theoretical and Applied Genetics, vol. 94, no. 5, pp. 597-602, 1997.

[19] I. Métais, C. Aubry, B. Hamon, R. Jalouzot, and D. Peltier, "Description and analysis of genetic diversity between commercial bean lines (Phaseolus vulgaris L.)," Theoretical and Applied Genetics, vol. 101, no. 8, pp. 1207-1214, 2000.

[20] J. J. Doyle and J. L. Doyle, "Insulation of seedling DNA from fresh tissues," X ray, vol. 12, pp. 13-15, 1990.

[21] N. A. Mantel, "The detection of disease clustering and a generalized regression approach," Cancer Research, vol. 27, no. 2, pp. 209-220, 1967.

[22] F. Liu, G. L. Sun, B. Salomon, and R. Von Bothmer, "Characterization of genetic diversity in core collection accessions of wild barley, Hordeum vulgare ssp. spontaneum," Hereditas, vol. 136, no. 1, pp. 67-73, 2002.

[23] X. P. Chen, L. Yan, and Y. Ding, "RAPD analysis and the probable evolutionary route of wild relatives of barley from China," Acta Botanica Sinica, vol. 42, no. 2, pp. 179-183, 2000.

[24] Z. Y. Feng, Y. Z. Zhang, L. L. Zhang, and H. Q. Ling, "Genetic diversity and geographical differentiation of Hordeum vulgare ssp. spontaneum in Tibet using microsatellite markers," High Technology Letters, vol. 10, pp. 46-53, 2003.

[25] V. Korzun, M. Roder, A. J. Worland, and A. Börner, "Intrachromosomal mapping of genes for dwarfing (Rht12) and vernalization response (Vrn1) in wheat by using RFLP and microsatellite markers," Plant Breeding, vol. 116, no. 3, pp. 227-232, 1997.

[26] C. Feuillet, G. Schachermayr, and B. Keller, "Molecular cloning of a new receptor-like kinase gene encoded at the Lr10 disease resistance locus of wheat," Plant Journal, vol. 11, no. 1, pp. 4552, 1997.

[27] P. Sourdille, M. R. Perretant, G. Charmet et al., "Linkage between RFLP markers and genes affecting kernel hardness in wheat," Theoretical and Applied Genetics, vol. 93, no. 4, pp. 580-586, 1996.

[28] G. A. Penner, J. Clarke, L. J. Bezte, and D. Leisle, "Identification of RAPD markers linked to a gene governing cadmium uptake in durum wheat," Genome, vol. 38, no. 3, pp. 543-547, 1995. 
[29] J. K. Roy, M. Prasad, R. K. Varshney et al., "Identification of a microsatellite on chromosomes 6B and a STS on 7D of bread wheat showing an association with preharvest sprouting tolerance," Theoretical and Applied Genetics, vol. 99, no. 1-2, pp. 336-340, 1999.

[30] M. Prasad, R. K. Varshney, A. Kumar et al., "A microsatellite marker associated with a QTL for grain protein content on chromosome arm 2DL of bread wheat," Theoretical and Applied Genetics, vol. 99, no. 1-2, pp. 341-345, 1999.

[31] T. Demeke, A. Laroche, and D. A. Gaudet, "A DNA marker for the Bt-10 common bunt resistance gene in wheat," Genome, vol. 39, no. 1, pp. 51-55, 1996.

[32] L. Qi, M. Cao, P. Chen, W. Li, and D. Liu, "Identification, mapping, and application of polymorphic DNA associated with resistance gene Pm21 of wheat," Genome, vol. 39, no. 1, pp. 191-197, 1996.

[33] K. G. Campbell, C. J. Bergman, D. G. Gualberto et al., "Quantitative trait associated with kernel traits in a soft $\mathrm{x}$ hard wheat cross," Crop Science, vol. 39, no. 4, pp. 1184-1195, 1999.

[34] J. A. Udall, E. Souza, J. Anderson, M. E. Sorrells, and R. S. Zemetra, "Quantitative trait loci for flour viscosity in winter wheat," Crop Science, vol. 39, no. 1, pp. 238-242, 1999.

[35] S. Naik, K. S. Gill, V. S. P. Rao et al., "Comparative analysis of genetic similarity among maize inbred lines detected by RFLPs, RAPDs, SSRs, and AFLPs," Theoretical and Applied Genetics, vol. 97, no. 8, pp. 1248-1255, 1998.

[36] A. A. Galande, R. Tiwari, J. S. S. Ammiraju et al., "Genetic analysis of kernel hardness in bread wheat using PCR-based markers," Theoretical and Applied Genetics, vol. 103, no. 4, pp. 601-606, 2001.

[37] F. Guasmi, L. Touil, K. Féres, N. Marzougui, W. Elfalleh, and A. Ferchichi, "Variety identification and genetic relationship of some South Tunisian barley accessions using agronomic parameters," Journal of Food, Agriculture and Environment, vol. 7, no. 2, pp. 522-527, 2009.

[38] E. D. Owuor, A. Beharav, T. Fahima, V. M. Kirzhner, A. B. Korol, and E. Nevo, "Microscale ecological stress causes RAPD molecular selection in wild barley, Neve Yaar microsite, Israel," Genetic Resources and Crop Evolution, vol. 50, no. 2, pp. 213 224, 2003.

[39] E.-H. Dakir, M.-L. Ruiz, P. García, and M. Pérez de la Vega, "Genetic variability evaluation in a Moroccan collection of barley, Hordeum vulgare L., by means of storage proteins and RAPDS," Genetic Resources and Crop Evolution, vol. 49, no. 6, pp. 619-631, 2002.

[40] D. Edward, B. Owuor, F. Tzion, B. Avigdor, A. Korol, and E. Nevo, "Population genetic response to microsite ecological stress in wild barley, Hordeum spontaneum," Molecular Ecology, vol. 6, no. 12, pp. 1177-1187, 1997.

[41] Y. Q. Yin, D. Q. Ma, and Y. Ding, "Analysis of genetic diversity of hordein in wild close relatives of barley from Tibet," Theoretical and Applied Genetics, vol. 107, no. 5, pp. 837-842, 2003. 


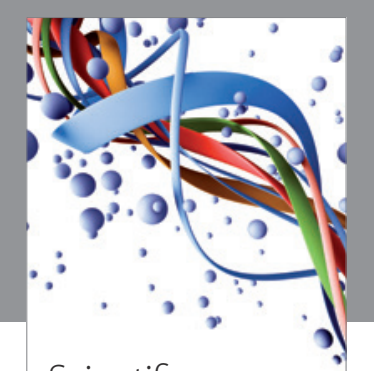

Scientifica
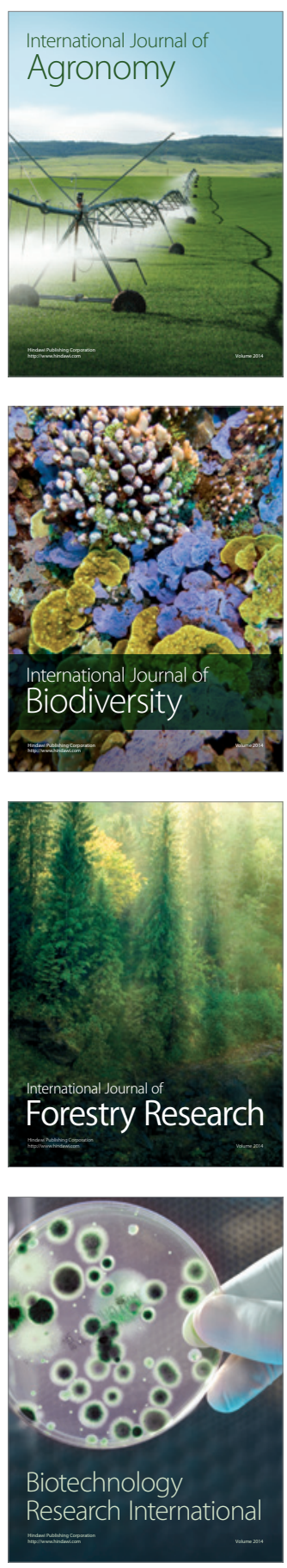
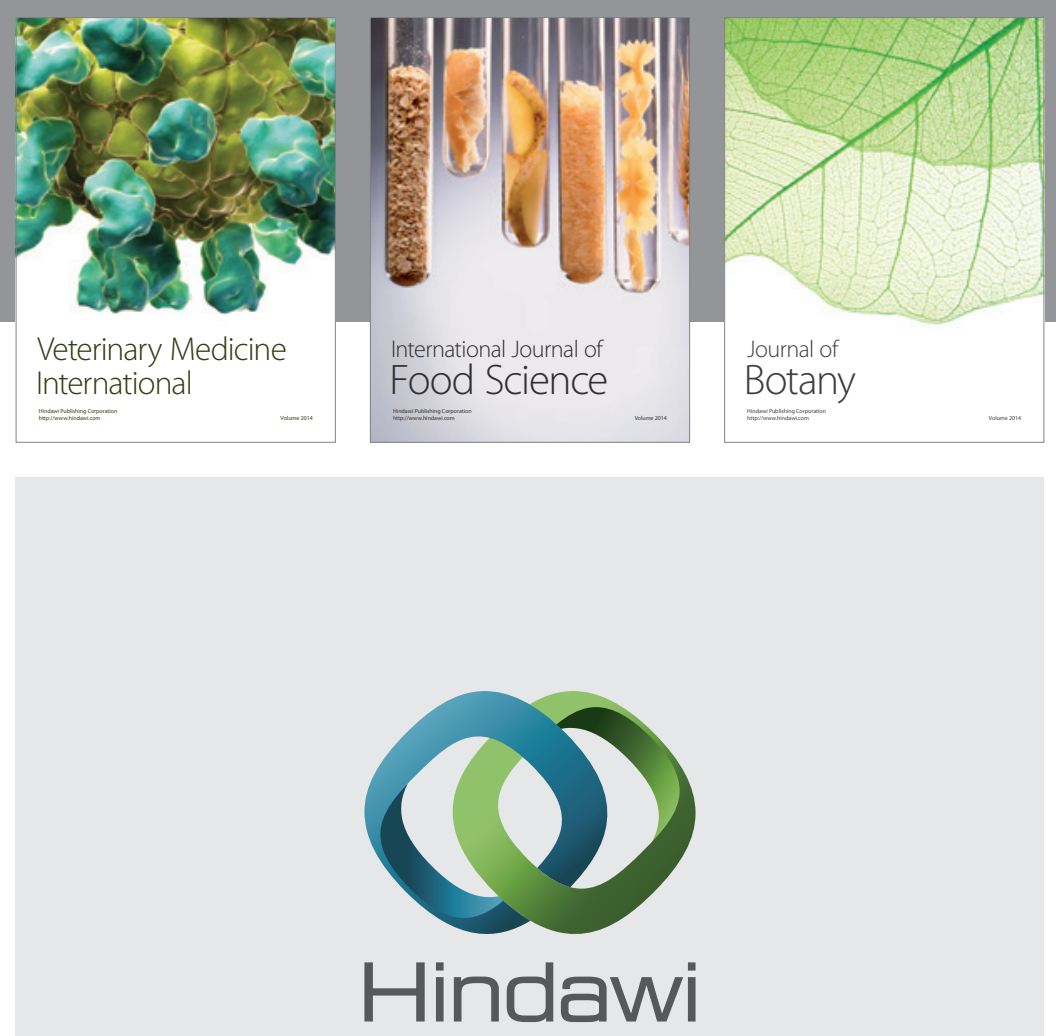

Submit your manuscripts at

http://www.hindawi.com
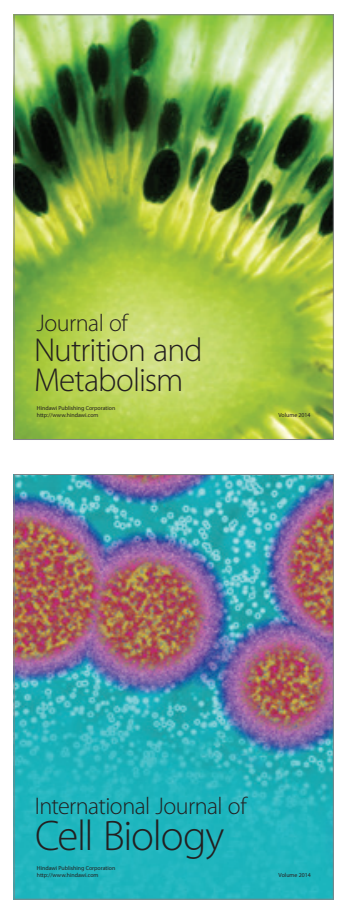
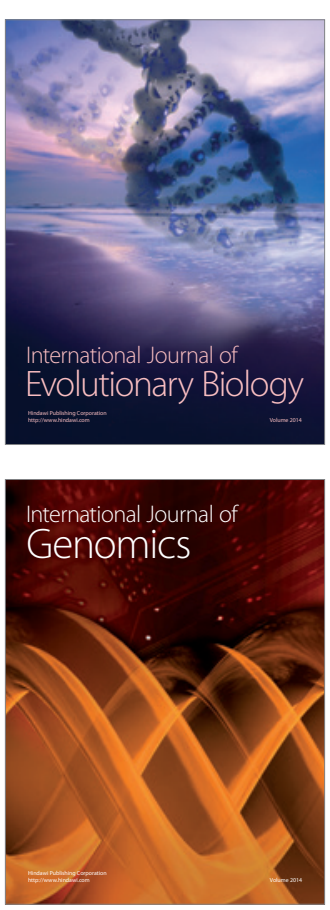
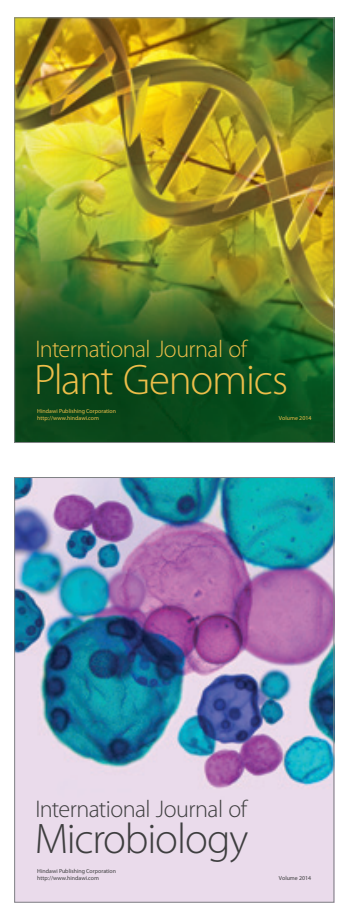

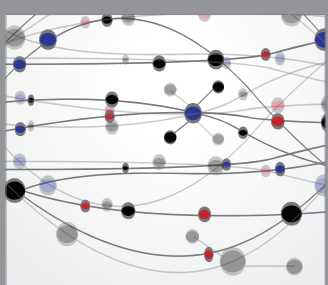

The Scientific World Journal
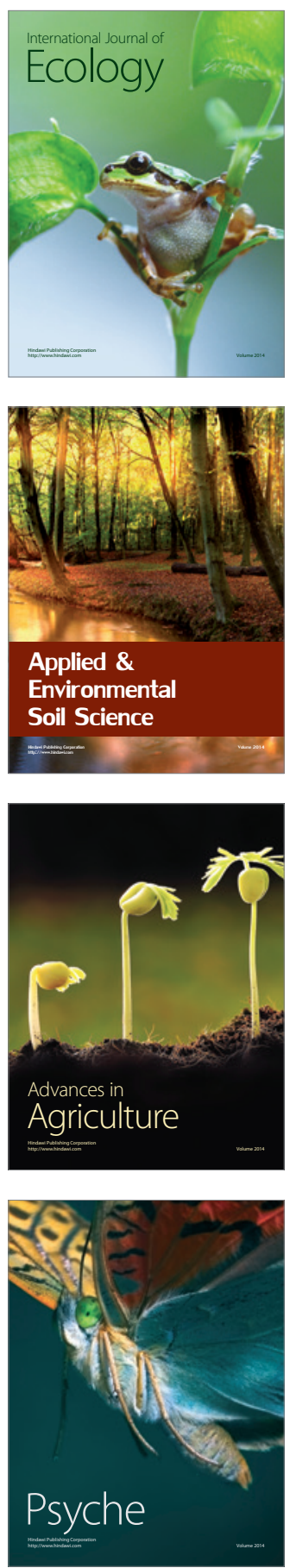